\title{
Board Member Age Diversity and Financial Performance of Manufacturing Firms: A Developing Economy Perspective
}

\author{
Richard Akisimire*1, Muhsin Salim Masoud ${ }^{2}$, Mutahyoba D. Baisi² ${ }^{2}$ Laura A. Orobia $^{1}$ \\ ${ }^{1}$ Makerere University Business School, Kampala, Uganda \\ ${ }^{2}$ University of Dar es Salaam Business School, Dar es Salaam, Tanzania \\ rakisimire@mubs.ac.ug, Masoud@amanabank.co.tz, baisi@udbs.udsm.ac.tz, lorobia@mubs.ac.ug
}

\begin{abstract}
This paper examines the relationship between board member age diversity and financial performance of manufacturing firms in Uganda. A cross section survey research design was employed using 78 manufacturing firms across the country. Data was analysed using descriptive statistics, chi-square analysis and point bi-serial correlation. The results showed that majority of the boards had members with an average age of 35-44years, followed by 25-34 years. In addition, boards comprising of majorly young board members registered low performance level, compared to the boards comprising of majorly older members. Further, the results indicated that board member age diversity is significantly associated with financial performance of manufacturing firms. Like any other research study, this study is limited in the following ways. Since only a single research methodological approach was employed, future research could undertake a mixed approach and triangulate to validate the current findings. Further, a longitudinal approach should be employed to study financial performance trends among manufacturing firms over years. Finally, board member age diversity was studied and by virtual of the results, there are other factors that explain the financial performance of the Uganda's manufacturing sector that were not part of this study.
\end{abstract}

Keywords: Age diversity, financial performance, manufacturing firms, board member

\section{Introduction}

In this study, we investigate the relationship between board member age diversity and financial performance of manufacturing firms in a developing economy where literature is currently scarce. Precisely, we principally report on the differences of the board member age composition and the effect that it has on financial performance. While good financial performance is a target of every rational business enterprise, many enterprises both in developing and developed economies have had challenges of poor financial performance (Nkundabanyanga, 2012; Kamukama, 2011; Baisi, 2008). Financial performance is seen in different contexts but generally, it can be measured in terms of liquidity, capital growth, asset base, return on assets and return on investment (Martin, 2013; Hofmann \& Lampe, 2013). Dagsson (2011) argue that board age diversity is among the factors that explain financial performance of any kind of organisation.

Effective execution of board duties and the consequent financial performance depends on how well the board is composed in terms of age distribution (Dagsson, 2011; Nyirenda, (2010). While well constituted boards are important for successful financial performance (Al-Saidi \& Al-Shammari, 2013), there is scanty literature about what constitutes an effective age diverse board and how this fosters the financial performance of manufacturing enterprise. Most of the research in the context of board age diversity has been conducted in government parastatals and listed companies, leaving non-listed companies and other private sector firms unstudied. And yet, these firms have been, and still remains the main Engine of the structural transformation of their host economies (Mutambi et al., 2010). For example; the Ugandan industrial manufacturing sector is one of the economic pillars of the economy and contributes 24\% of the country's GDP, (UBOS, 2011; World Bank, 2013). However, the sector is still small and slow growing compared to the other economies in the region where the sector's GDP contribution reaches a peak at 30-40 percent (Ishengoma \& Kapel, 2008). The low GDP contribution of the sector is attributed to slow growth that is as a result of poor financial performance (Mutambi, 2011). One key area that has attracted debate is the issue of corporate boards especially; how these boards are composed in terms of board age diversity, (Bathula, 2008; Khan and Awan, 
2012). And yet, there is need for a broader understanding of boards and their effect on the financial performance in a multispectral context to avoid the assumption of a "one size fits all" phenomenon (Davies \& Schlitzer, 2008; Fu \& Yu, 2008). Notably, age diversity has been cited in most debates as influential in predicting the financial performance of most companies (Dagsson, 2011; Nyirenda, 2010). However, most of these debates have produced conflicting results. Even then, most studies mainly tested listed firms in a developed economy context thus side lining the private manufacturing sector in a developing economy perspective. As a result, poor financial performance has largely remained unexplained in the context of the developing economies especially in the Ugandan manufacturing sector (Nkundabanyanga, 2012; Mutambi, 2011). Most firms in the manufacturing sector have registered a low return on investment, low return on assets and some of them fail to maintain adequate liquidity levels (Ishengoma \& Kapel, 2008). In an attempt to fill this evident gap, there is need to investigate the central challenge of poor financial performance focusing on the context specifics.

Most of the studies related to board age diversity and financial performance borrow ideologies from the developed economies, leaving the developing economies to rely on unlocalised ideologies. Yet, business firms in developing countries operate in unique environments and face different board challenges. The study contributes to the existing academic research by providing empirical evidence in the examination of these theories in the context of a developing economy. More so, earlier studies in the area of financial performance have over looked the paramount importance of board age diversity as predictor. This study therefore contextualises the debate in the a private sector setting by employing a multi theoretical approach as well as establishing the best model for effective board age diversity as a predictor to effective financial performance. At a managerial and policy level, manufacturing firms especially in developing economies will use study findings to improve their boards especially with the way they are constituted in terms of their age diversity. This will provide guidelines about the key success factors of age diverse board as a tool to improve financial performance. The rest of the paper proceeds as follows: the next section presents literature review and hypotheses development. This is followed by the research methodology. The results and discussion are presented next while the final section covers the conclusion and implication.

\section{Literature Review}

The Agency Theory: According to this theory, there are two parties in a firm; the principal and the agent. The principal owns the firm and the agent controls the operations of that firm (Berle \& Means, 1932). The theory postulates that the agent is expected to act on behalf of the principal with control and consent (Jensen \& Meckling, 1976; Freeman, 1984; Muneer et al., 2013). The principals invest capital in the company and design mechanisms or governance systems to maximize their returns as represented by the board (Clarke, 2004; Brown, 2008). This implies that a well composed board with a significant diversity may be in a better position to provide controls as well as ensuring effective performance (Pastoriza \& Miguel, 2008). Because of this, a diverse board with the relevant expertise and experience may be required in the provision of such controls. Perhaps, this is achieved if a board is composed of different age groups with such diverse expertise and experience. In the perspective of a private sector, the board plays an important internal mechanism role of resolving the agency problems (Clarke, 2004). This equally calls for proactive and innovative board members to execute such roles. Of which, young board members can best serve the purpose (Nkundabanyanda, 2012; Clarke, 2004). Similarly, older board members use their experience to advice management as well as performing other oversight function (Brown, 2008). In a summary, monitoring management on behalf of the corporation's shareholders, making decisions regarding the selection, compensation and evaluation of a well qualified and ethical CEO is the single most important function of the board (Berle \& Means, 1932; Brown, 2008). However, the agency theory has also been criticised for its narrow focus on large and listed companies and yet, private entrepreneurial firms also equally suffer from agency problems. Thus, the current study adds to the existing literature by testing the theory to explain governance practices in the private sector setting.

Stakeholder Theory: This theory assumes that firms should recognise the responsibility to all those affected by their operations (Freeman, 1984). Principally, the theory is articulated in the purpose of the firm and what brings its core stakeholders together (Donaldson \& Preston, 1995; Freeman, 1984a; Freeman et al., 2004). 
The assumption here is that, a company exists to serve all the stakeholders who have an interest in it or who in some way may benefit from its operations (Freeman, 1984). Additionally, Bathula (2008) contends that the stake holder theory is an extension of the agency view which expects the board to take care of the interests of the shareholder and that shareholders have undergone change. Thus, the boards are now expected to take into account the interest of many stakeholder groups. In a practical sense, the various decisions taken by an age diverse board may take into account the many stakeholders of different age groups. This is because age diverse boards help to influence management on the type of product lines to adapt so as to cater for customer needs of different age categories in a more sensitive manner, and this may in the long run boost the firm's revenues, something that propels the firm forward and allows it to generate outstanding financial performance (Daggson, 2011).

Resource Dependence Theory: The theory views boards as boundary spanners who pull intellectual resources courtesy of their experience and skills to increase the competitive advantage for the firm (Pfeffer \& Salanick, 1978; Pfeffer, 1972; Huse, 2005). And because age is seen to be an "indirect resource" (Huse, 2005; Pfeffer, 1972). It implies that an age diverse board provides diverse knowledge, skill and experience while executing their duties. The theory brings insights that an age diverse board creates a "cobweb" of knowledge exchange from the different age groups (Nkundabayanga, 2012; Pfeffer \& Salanick, 1978). It is therefore arguably explicit that if a board is composed of older board members, they are expected to come along with diverse experience (business or otherwise) which they use to guide the management team in propelling the firm forward (Pfeffer, 1972; Pfeffer \& Salanick, 1978). Similarly, young board members are resourceful because they are proactive and innovative and thus are able to bring in a new outlook and create value on the board (Pfeffer, 1972; Abaho, 2014). Thus, in the perspective of the private manufacturing firms that have entrepreneurial attributes, age diverse boards are expected to have different entrepreneurial ideas and skills that help to boost firm performance. This calls for the inclusion of both young and old board members as long as they are resourceful in achieving good performance (Pfeffer, 1972; Pfeffer \& Salanick, 1978). Therefore, seeing the board as a pool of resources for a company helps to consider significant age diversity and opens up a very different way to think about the board's role in creating value through financial performance.

Manufacturing Sector in Uganda: The manufacturing sector consists of MSMEs which account for 95\% of the entire sector and employ more that 2.5 million people (UBOS, 2015). The UBOS (2015) report indicates that these MSMEs constitute $90 \%$ of the private sector contributing more than $20 \%$ of the GDP. The sector GDP contribution improved by $11 \%$ in the FY, 2015 much better than 2.2\% in the FY2013/14. Most of these manufacturing firms are located in urban and pre urban areas country wide and are involved in trade, agroprocessing and small scale manufacturing (GoU, 2000). Most importantly, the sector has been, and still remains the main Engine of the Uganda's structural transformation (MoFPED, 2012; Mutambi et al., 2010). Unfortunately, the sector still faces challenges of poor financial performance and slow growth something that undermines the countries ambition to industrialize the sector (Ishengoma \& Karpel, 2008). However, the basis of Uganda's future prosperity and competitive growth depends on the existing and future entrepreneurial firms; manufacturing industries inclusive (Orobia et al., 2013; Ahimbisibwe et al., 2016). With the establishment of the East African community, it is expected that the Ugandan manufacturing sector will greatly benefit from access to the markets of the member states as well as internationally (NPA, 2010).

Besides, because the Ugandan Government has a vision of transforming the economy from a low developing to a middle income economy under the "Vision 2040" (NPA, 2010; UNIDO, 2013), the main focus is a private sector driven economy and the government has embarked on the aggressive promotion of the private sector by encouraging value addition through industrialization to a level associated with middle income economies (NPA, 2010; World Bank, 2013; Mutambi et al., 2010). Unfortunately, the sector is still faced with challenges of survival as a result of poor financial performance. For example, more than $30 \%$ of the manufacturing firms have not able to witness their fifth birth day (Ocici, 2006; Orobia et al., 2013).Uganda being a developing economy; it is disadvantaged in terms of low level industrial manufacturing position (UBOS, 2015). Thus, efforts to understand the financial performance of the manufacturing sector are paramount for the growth of the private sector which is essential in ensuring the overall economic growth. Lest, any attempt to expand the sector would be fruitless if not matched with the way their governing boards are composed with diverse age groups. 
Firm Financial Performance: Although there are different perspectives of looking at firm performance, this study focused on financial performance. Financial performance of a firm can be assessed differently including turn over and liquidity which measures the ability of a business to meet financial obligations as they come due, without disrupting the normal, ongoing operations of the business (Kamukama, 2011; Abdelmohsen et al., 2013; Tumwine et al., 2015). Profitability is another dimension of financial performance which indicates the extent to which a business generates profit from the factors of production such as labor, management and capital (Kreusel \& Christian, 2008; Hofmann \& Lampe, 2013). Profitability is seen in terms of rate of return on assets (ROA), return on equity (ROE), operating profit margin and net income (Pandey, 1997).

Different scholars view financial performance differently. For example; while establishing a borrowing cost model for effective performance of SMEs in Uganda, Tumwine et al. (2015) measured financial performance in terms of liquidity, sales level and Asset base. According to Ishengoma and Karpel (2008), growth over a period of time can be used as a measure of performance in manufacturing firms. Mutambi (2011) also describes key performance indicators among manufacturing firms in terms of investment in plant and machinery, output and other capital investments. Mutambi (2011) further argues that key performance indicators among manufacturing firms need to be understood because a new paradigm of performance measures has been adopted by many firms. The main reason for using these KPIs includes; telling how well the products are manufactured, product delivery performance and overall measurement of turnover level something that would in the long run increase the return on capital employed and profit margin (Kasekende \& Opondo, 2003). On the contrary, Nkundabanyanga (2012) while analysing the perceived performance among the Ugandan service firms concluded that good financial performance indicators include; good equity returns, controlled expenditure and profitable investments as well as happy shareholders in terms of dividends received. Notwithstanding the different schools of thought about financial performance, the current study operationalises firm performance in terms of firm's revenues, asset base, return on assets, return on investment and profit after tax as measures of financial performance.

Board member age diversity and financial performance: It has been argued that the average board member age varies depending on the economic setting of different countries and the average employee age (Dagsson, 2011). In Britain for example, some 30\% of the UK working-age population is over 50, in the United States census data (2008-2010) shows that age group of board members was between 45- to 54 years (Catalyst, 2011). In China, research indicates that three age groups of employees, namely, 45- to 59-year-olds, 60- to 64-year-olds, and over 65-year-olds, are increasing rapidly (Liu \& Michelle, 2010). It was also found out that the average age of a director in Hong Kong 2011 is over 58 (Catalyst, 2011). However, when addressing age as an element of diversity, there are many facets to consider; Khan and Awan (2012) emphasized that older board members bring more experience and skills in the board room. Wellalage and Locke (2013) contend that younger board members bring more energy and new outlook. Similarly, Nyirenda (2010) argues that younger board members come along with morale and productivity to boost firm performance. Li et al. (2011) in their study of cross cultural antecedents of firm performance, found a significant and positive effect of age diversity and a significant interactive effect between age diversity and firm strategy on profitability. The same study found a significant relationship between board age diversity and firm profitability. Dagsson (2011) found that age diversity significantly affects firm financial performance and argued that board age heterogeneity improves the ability of groups to solve tasks with high complexity which in turn indicates that groups of diverse age should be utilized particularly for innovation or solving complex problems. Drawing from the above discussion, we derive the following hypotheses:

H1: Boards with majorly young age groups are more likely to register better financial performance than the older age group in manufacturing firms in Uganda.

H2: There is a positive and significant relationship between board member age group and financial performance of manufacturing firms in Uganda.

\section{Methodology}

This study employed a cross-sectional survey design in that the phenomenon in question was studied at a particular period in time. The population consisted of 146 manufacturing firms that had boards and are registered members of the Uganda Manufacturers Association. Accordingly, a sample size of 108 was 
determined using the Krejcie and Morgan (1970)'s table of sample size determination. The sample elements were selected the Ms Excel random selector. A self-administered questionnaire approach was utilized to collect the field data. This was done alongside a documentary review on financial performance of the firms. However, only 78 firms responded (72 percent response rate). It is worth noting that five copies of the questionnaire were distributed to each selected firm to be filled by the board chairman, and four other board members. Nonetheless, the usable ones in this study were an average of three per firm.

Sample characteristics

Table 1: Descriptive Statistics - Respondents' Demographics

\begin{tabular}{lll}
\hline Variables & Freq & \% \\
\hline Education levels & 29 & 12 \\
UACE & 19 & 8 \\
Diploma & 102 & 43 \\
Degree & 54 & 23 \\
Masters & 31 & 13 \\
PhD & 235 & 100 \\
Total & & \\
Age groups & 6 & 3 \\
$26-33$ & 51 & 22 \\
$34-41$ & 48 & 20 \\
$42-49$ & 85 & 36 \\
$50-57$ & 45 & 19 \\
$58+$ & 235 & 100 \\
Total & & \\
Marital status & 29 & 12 \\
Single & 201 & 86 \\
Married & 5 & 2 \\
Divorced & 235 & 100 \\
Total & & \\
Gender & 162 & 69 \\
Male & 73 & 31 \\
Female & 235 & 100 \\
Total & & \\
\hline
\end{tabular}

Results in table 1 clearly show that, majority of the board members that participated in this study had a bachelor's degree as their highest education level (43\%); belonged to the $50-57$ years age group (36\%); were married (86\%) and were males (69\%). Considering the nature of boards, the results are presented in table 2 below.

Table 2: Nature of Board Directors

\begin{tabular}{lll}
\hline & Frequency & Percent \\
\hline Number of directors on the board & & \\
$3-6$ & 14 & 17.9 \\
$6-9$ & 59 & 75.6 \\
Over 9 & 5 & 6.4 \\
Total & 78 & 100.0 \\
How many female directors do you have on the board? & & \\
Less than 2 & 1 & 1.3 \\
$2-5$ & 75 & 96.2 \\
$5-10$ & 2 & 2.6 \\
Total & 78 & 100.0 \\
\hline
\end{tabular}




\begin{tabular}{lll}
\hline How many male directors do you have on the board? & \\
$2-5$ & 60 & 76.9 \\
$5-10$ & 18 & 23.1 \\
Total & 78 & 100.0 \\
Gender of the board chairperson & & \\
Male & 72 & 92.3 \\
Female & 6 & 7.7 \\
Total & 78 & 100.0 \\
Is the CEO the same as Board chairman? & & \\
Yes & 43 & 55.1 \\
No & 35 & 44.9 \\
Total & 78 & 100.0 \\
\hline
\end{tabular}

Most boards had 6-9 directors (42.6\%) while the least number is represented by board members less than 3 (1.7\%). This would imply that most the boards of manufacturing firms in Uganda are composed of board members who are at the same time directors or owner of the same firms.

\section{Operationalisation and Measurement of Variables}

Board member age diversity: Board member age diversity in this study was considered as a categorical variable. It was measured differently, due to the numerical value of age. Board member age diversity was measured by composing age groups and then measuring the percentage of board members in each age group. This was done by dividing per age group the amount of people in all sample companies in that group by the total amount of board members in all sample companies. This method is also used by Siciliano (1996).

Financial performance: The dependent variable, firm financial performance was considered as a continuous variable and measured in terms of firm revenue, return on assets, return on equity, return on investment and profit after tax. The financial performance data were captured by reviewing the financial reports from the registry of companies. For firms whose data was not in the archives of the registry, reference was made to the finance directors or accountants to provide financial information which was later anchored to a 5 point likert scale (1= "Less than 2\%", $\mathbf{2}=$ " 2 - 5\%", 3= "5 - 8\%", 4= "8 - 11\%", $\mathbf{5}=$ "Over 11"). This approach has been successfully employed by previous scholars like Kamukama (2011).

Data Analysis: Descriptive statistics analysis was used to describe the demographic characteristics of the study participants. A point-biserial correlation analysis was performed to measure the strength and direction of the association that exists between board member age diversity and financial performance. Chi-square analysis was performed to test the relationship between board member age diversity and financial performance. Specifically, the objective was to test if financial performance was the same for both the board members comprising of young and old age groups. In others words to test if the boards with the young age groups more than the old age group likely to register better financial performance. This was necessary to form an opinion on board composition in terms of age group. In performing the chi-square analysis, financial performance was coded using the visual binning function in SPSS: $1=$ "low", $2=$ "middle" and $3=$ "high performance".

\section{Empirical Results}

Information was sought on the average board member age across the manufacturing firms. The results are presented in table 3. 
Table 3: Distribution of Board Member Age

\begin{tabular}{lll}
\hline Age group & Frequency & Percent \\
\hline 25-34yrs & 27 & 34.6 \\
35-44yrs & 31 & 39.7 \\
$45-54 y r s$ & 13 & 16.7 \\
$55+y r s$ & 7 & 9.0 \\
Total & 78 & 100.0 \\
\hline
\end{tabular}

On the assessment of the average age group of the board members, the results show that majority of the respondents lie in the age group of $35-44$ years represented by $39.7 \%$, followed by those in the age group of 25 -34- years (34.6\%) while the least represented group was above 55 years at the time this data was collected. This implies that most boards of manufacturing firms in Uganda are composed of middle age board members.

Table 4: Descriptive Statistics of Financial Performance

\begin{tabular}{lllll}
\hline Item & Min. & Max. & Mean & Std. Dev \\
\hline Firm Revenue & 1.00 & 5.00 & 2.432 & 0.613 \\
Asset Base & 1.00 & 5.00 & 2.637 & 0.730 \\
Return On Investment & 1.00 & 5.00 & 2.462 & 0.584 \\
Return On Assets & 1.00 & 5.00 & 2.179 & 0.684 \\
Profits After Tax & 1.00 & 5.00 & 3.158 & 0.729 \\
Financial Performance & 1.00 & 5.00 & 2.574 & 0.482 \\
\hline
\end{tabular}

The results show that on average the improvement of the overall financial performance of the manufacturing firm under the survey ranged between 5\% - 8\%. Considering the indicators of financial performance, the results show that on average the firms surveyed registered higher increase in profits after tax followed by the asset base. The least performance indicator was return on assets.

Chi-Square Analysis: Information was sought on the relationship between board member age diversity and financial performance using chi-square analysis. Specifically, the analysis was to test if financial performance was the same for both the board members comprising of young and old age groups. In other words to test if the boards with the young age groups more than the old age group were likely to register better financial performance. The results are presented in table 5 below.

Table 5: Financial Performance * Board Age Diversity Cross Tabulation

\begin{tabular}{|c|c|c|c|c|}
\hline & & \multicolumn{2}{|c|}{ Board Age Diversity } & \multirow[t]{2}{*}{ Total } \\
\hline & & Young & Old & \\
\hline \multirow{8}{*}{ 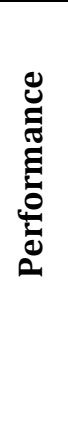 } & Low & 23 & 2 & 25 \\
\hline & & $39.7 \%$ & $10.0 \%$ & $32.1 \%$ \\
\hline & Middle & 21 & 5 & 26 \\
\hline & & $36.2 \%$ & $25.0 \%$ & $33.3 \%$ \\
\hline & High & 14 & 13 & 27 \\
\hline & & $24.1 \%$ & $65.0 \%$ & $34.6 \%$ \\
\hline & & 58 & 20 & 78 \\
\hline & & $100.0 \%$ & $100.0 \%$ & $100.0 \%$ \\
\hline
\end{tabular}

Pearson chi-square $=11.81 ; \mathrm{d} f=2 ;$ Asymp sig $=.003$ 
In table 5, the percentage downward result show that majority (39.7\%) of the boards comprising of young board members registered the low performance level. This was contrary to the older age group. The percentage downward results of the older age group showed that such boards registered high performance level (65\%). Comparing the two columns (young versus old age groups), an initial conclusion can be drawn that there was a big difference in financial performance levels between the young and old age groups. The difference is more vivid at low and high performance levels. Looking at the significance levels, the results reveal a significant relationship between age diversity and financial performance in the current study. Further information was sought on how financial performance varied across the detailed age groups, for a more enriched position. The results are presented in table 6.

Table 6: Financial Performance * Detailed Board Age Diversity Cross Tabulation

\begin{tabular}{|c|c|c|c|c|c|c|}
\hline & & \multicolumn{4}{|c|}{ Board Age Diversity } & \multirow[t]{2}{*}{ Total } \\
\hline & & $25-34 y r s$ & $35-44 y r s$ & 45-54yrs & $55+y r s$ & \\
\hline \multirow{8}{*}{ 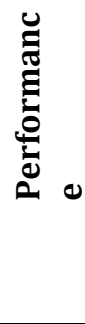 } & Low & 12 & 11 & 2 & 0 & 25 \\
\hline & & $44.4 \%$ & $35.5 \%$ & $15.4 \%$ & $0.0 \%$ & $32.1 \%$ \\
\hline & Middle & 9 & 12 & 3 & 2 & 26 \\
\hline & & $33.3 \%$ & $38.7 \%$ & $23.1 \%$ & $28.6 \%$ & $33.3 \%$ \\
\hline & High & 6 & 8 & 8 & 5 & 27 \\
\hline & & $22.2 \%$ & $25.8 \%$ & $61.5 \%$ & 71.4\% & $34.6 \%$ \\
\hline & & 27 & 31 & 13 & 7 & 78 \\
\hline & & $100.0 \%$ & $100.0 \%$ & $100.0 \%$ & $100.0 \%$ & $100.0 \%$ \\
\hline
\end{tabular}

Pearson chi-square $=12.86 ; d f=6 ;$ Asymp sig $=.045$

The percentage downward result show that majority of the boards had an average age group of $35-44$ years $(31 / 78 * 100=39.7 \%)$; followed by the $25-44$ years age group. Further, the percentage downward results show that majority of the firms that registered low performance levels had boards in age bracket of $25-34$ years. More still, majority of the firms that registered middle performance levels had boards in age bracket of 35 - 44years; while majority of the older age categories registered high performance levels.

Correlation Analysis: Information was also sought on the relationship between board age diversity and financial performance using point biserial correlation. The results are presented in table 7 below.

Table 7: Correlation Analysis

\begin{tabular}{llllllll}
\hline & $\mathbf{1}$ & $\mathbf{2}$ & $\mathbf{3}$ & $\mathbf{4}$ & $\mathbf{5}$ & $\mathbf{6}$ & $\mathbf{7}$ \\
\hline Board member age diversity -1 & 1.000 & & & & & & \\
Firm Revenue -2 & $.269^{*}$ & 1.000 & & & & & \\
Asset Base -3 & .211 & $.517^{* *}$ & 1.000 & & & & \\
Return On Investment -4 & .220 & $.485^{* *}$ & $.631^{* *}$ & 1.000 & & & \\
Return On Assets -5 & $.430^{* *}$ & $.475^{* *}$ & $.379^{* *}$ & $.496^{* *}$ & 1.000 & & \\
Profits After Tax -6 & $.350^{* *}$ & $.296^{* *}$ & .136 & $.231^{*}$ & $.433^{* *}$ & 1.000 & \\
Financial Performance -7 & $.413^{* *}$ & $.753^{* *}$ & $.736^{* *}$ & $.767^{* *}$ & $.771^{* *}$ & $.598^{* *}$ & 1.000 \\
\hline
\end{tabular}

*. Correlation is significant at the 0.05 level (2-tailed).

**. Correlation is significant at the 0.01 level (2-tailed).

The results in table 7 show that there is a positive and significant relationship between board member age diversity and financial performance of manufacturing firms $\left(\mathrm{r}_{\mathrm{pb}}=.413, \mathrm{p}<.01\right)$. This can be interpreted as a positive change in board member age diversity of the board is associated with a positive change in financial performance. Considering the relationship between the separate indicators of financial performance, the results reveal that board member age diversity is significantly associated with firm revenue $\left(\mathrm{r}_{\mathrm{pb}}=.269\right.$, $\mathrm{p}<.05)$, return on assets $\left(\mathrm{r}_{\mathrm{pb}}=.430, \mathrm{p}<.01\right)$ and profit after tax $\left(\mathrm{r}_{\mathrm{pb}}=.350, \mathrm{p}<.01\right)$. While the relationships between board member age diversity and asset base and return on investment were insignificant $\left(r_{p b}=.211\right.$, $\mathrm{p}<.01 ; \mathrm{r}=.211, p<.01$ respectively). This implies that asset base and return on investment are inconsequential in the association with board member age diversity in the case of manufacturing firms in Uganda. 
Regression Analysis: Information was sought on the predictive power of the model specified in this study. The results are presented in table 8 .

Table 8: Regression Results

\begin{tabular}{|c|c|c|c|c|c|c|c|c|c|c|}
\hline & \multicolumn{2}{|c|}{$\begin{array}{l}\text { Unstandardized } \\
\text { Coefficients }\end{array}$} & \multirow{2}{*}{$\begin{array}{l}\text { Standardized } \\
\text { Coefficients } \\
\text { Beta }\end{array}$} & \multirow[t]{2}{*}{$\mathrm{T}$} & \multirow[t]{2}{*}{ Sig. } & \multicolumn{2}{|c|}{$\begin{array}{l}\text { Correlations } \\
\text { Zero- }\end{array}$} & \multirow[b]{2}{*}{ Part } & \multicolumn{2}{|l|}{$\begin{array}{l}\text { Collinearity } \\
\text { Statistics }\end{array}$} \\
\hline & B & Std. Error & & & & order & Partial & & Tolerance & VIF \\
\hline (Constant) & 1.358 & .229 & & 5.935 & .000 & & & & & \\
\hline Experience Diversity & .369 & .108 & .346 & 3.411 & .001 & .432 & .366 & .334 & .929 & 1.076 \\
\hline Board Age Diversity & .279 & .088 & .321 & 3.167 & .002 & .413 & .343 & .310 & .929 & 1.076 \\
\hline \multicolumn{11}{|c|}{$R=.531 ; R^{2}=.282 ;$ Adj $R^{2}=.263 ; F$-Statistic $=14.7 ;$ Sig $=.000$} \\
\hline
\end{tabular}

The results show that a predictive power of $26.3 \%$ (Adj $\mathrm{R}^{2}=.263$ ). In addition, the results confirm the correlation results which revealed a positive and significant relationship between board member age diversity and financial performance $(\beta=.342, \mathrm{p}<.05)$. Board member experience diversity was used in the model as a confounding variable, and relationship was found to be significant $(\beta=.346, p<.05)$. These results are discussed in the next section.

Discussion: The results on the relationship between board member age diversity and financial performance indicate a significant and positive relationship. This implies that, positive variations in board member age diversity are associated with positive variations in financial performance of manufacturing firms in Uganda. Considering the variable board member age diversity, existing literature indicates that young board members are proactive and innovative and thus are able to bring in a new outlook and create value on the board. In addition, the young stars are considered ambitious and risk takers. Ideally, being proactive and innovative should be associated with high performance, given that such attributes are meant to improve efficiency. The results in this study revealed that boards with majorly young age group were associated with low performance. This is true because most Ugandan young stars have less business experience and so cannot on their own offer valuable management advise to drive performance. In addition, they are very volatile and as such, they tend to make hasty investment decisions without thorough calculations as well as evaluating the consequences. In fact, such decisions often turn into huge expenses that consequently erode the companies' profits and finances (Daggson, 2011). The younger age group are technology savvy and given that they are high risk takers, they tend to take their chances in investing in high technology as well as acquiring assets to improve efficiency. All this cannot be said of the older age group. The older age group are considered calculative and risk averse and this has an impact on their decision making process (Abaho, 2014). The older age group are considered to be more experienced and perhaps provide more critical advice in the decision making process (Bathula, 2008). Therefore, firms need to have a mix of the young and the old members to neutralize age effects (Daggason, 2011; Nkundabanyaga, 2012; Abaho, 2014)

From the stake holders theory perspective, finding also offer reasonable support to the theory which views diversity to be beneficial to the firm (Freeman et al., 2004; Clarke, 2004). This is because various decisions taken by an age diverse board may take into account the many stakeholders of different age groups. This study argues that age diverse boards help to influence management on the type of product lines to adapt so as to cater for customer needs of different age categories in a more sensitive manner, something that may boost the firm's revenues (Daggson, 2011). Considering the resource dependency theory, the theory posits that age is an "indirect resource" (Huse, 2005; Pfeffer, 1972; Pfeffer \& Salanick, 1978). The theory postulates that board members with diverse age groups are expected to come along with different perspectives of viewing issues on the board courtesy of their age calibre. Previous studies have established that age diversity provides diverse knowledge, skill and experience required to improve performance. For instance, Khan and Awan (2012) in their study report that, whereas younger board members are innovative, older board members bring more experience and skills in the board room. The findings are in line with those of Abaho (2014) who contends that younger cadres are perceived to be proactive and quick in their decision making processes. For example, while analysing age as an antecedent to entrepreneurial values among university students in 
Uganda, Abaho observed that different age groups have different entrepreneurial values and noted that people between 25 and 34 are more entrepreneurial. The researcher argued that even when young people make mistakes, they believe they have an ample time to fix them unlike the older ones.

Further findings by Wellalage and Locke (2013) show that younger board members bring more energy and new outlook to the organisation. Even then, older board members have tendency of being rigid in decision making with fear to haunt their reputation and corporate image of the firms they represent (Nyirenda, 2010; Khan \& Awan, 2012). This would confirm that having the right mix of both young and old board members would add value to the financial performance of the firm. Interestingly, Nyirenda (2010) adds that age diversity significantly affects firm financial performance and because age heterogeneity improves the ability of groups to solve tasks with high complexity which in turn indicates that groups of diverse age should be utilized particularly for innovation or solving complex problems. Dagsson (2011) in a study of 258 firms listed on the OMX stock exchange established a significant relationship between age diversity and financial performance of the firms. Surprisingly, an observation made is that age is not fundamentally considered while selecting board members in some private sector firms but rather; proprietors of these manufacturing firms were observed to prefer choosing family members and friends courtesy of their corporate status as long as they have the will to undertake the duties. Additionally, Kunze et al. (2013), while investigating organizational performance consequences of age diversity among 147 companies in Switzerland observed related views like those of the current study. The researchers found out that age diversity is a paramount predictor of age organizational performance and further suggest that for companies to achieve sustainable performance, they need to always consider age diversity on their top management teams. Drawing from the above discussion, the current study findings therefore imply that with a right mix of age groups, there is a high possibility of improving the firm's financial performance.

\section{Conclusion and Implications}

The findings and discussion above lead to the conclusion that, age diversity is strongly and positively related with the financial performance of manufacturing firms in Uganda. From the theoretical perspective, the study findings provide support for the stakeholder theory, by providing evidence indicating that stakeholder differences in terms of age diversity is associated with financial performance of manufacturing firms. Looking at the resource dependency theory perspective, this paper also provides a partial confirmation that age is indeed an indirect resource since it was confirmed that, whereas older age group come along with experience and perhaps provide more critical advice in the decision making process, young board members are proactive and innovative and thus are able to bring in a new outlook and create value on the board. The study therefore adds to the existing body of theoretical knowledge by contending that; other than external board members who are seen as a resource courtesy of their networks and experience, age diversity on the board is also a significant resource that must be considered. Thus, if firms are to make strategic and effective use of their respective boards to improve their financial performance, they need to pay attention to board member age diversity and ensure that there is a proper mix of the age groups among the board members. This paper therefore provides insights on why firms should prefer age diverse boards and indeed confirms that having the right age mix on the board will help to guide manufacturing firms in improving their performance. The current study therefore sets to add a significant body of knowledge to the on-going debate in the area of firm financial performance. The study also brings a lime light to the debate of board member age diversity a new perspective of manufacturing firms. For managerial implications, study highlights the magnitude of ability for the private manufacturing firms to constitute reasonable board by specifically focusing on the age diversity among board members as a means of boosting performance levels. The current study therefore appeals to the proprietors and/or share holders of manufacturing firms to continuously have the right mix of the individuals they select at the point of constituting their board. This would fundamentally improve manner in which decisions are made regarding the strategic approach and choice of the different product lines as well as the business acumen to adapt while considering the different age groups of clients, something that would in destiny influence the financial performance of firms.

Additionally, given the paramount contribution of the manufacturing sector to the Economy to a tune of over $24 \%$, of Gross Domestic Product, there is fundamental need for the government and other respective 
stakeholders to develop an enthusiastic interest in the extent to which age diverse boards of these firms are effectively constituted in a bid to harness financial performance. This would help to reduce challenges of "homogeneous boards" (Nkundabanyanga, 2016). Moreover, given the competitive, dynamic and turbulent business environment in which manufacturing firms operate in the 21st Century, manufacturing entrepreneurs must appreciate that a "modern-day" company changes so rapidly, that everything is reliant on the proactiveness of top echelons as well as experience and strength of networks from board members. Thus, such antecedents must be put at the fore front while selecting board members especially with diverse age groups. Lastly, manufacturing entrepreneurs and their management teams should attempt to put on top of their priority agenda list the most appropriate age mix that fits the operational needs of their firms. This is because of the new technological developments, new product lines and other firm strategic activities that could easily require the intervention of age diverse boards. Like any other research study, this study is limited in the following ways. A single research methodological approach was employed; future research could undertake a mixed approach and triangulate to validate the current findings. Further, a longitudinal approach could be employed to study financial performance trends among manufacturing firms over years. Finally, board member age diversity was studied and by virtual of the results, there are other factors that explain the financial performance of the Uganda's manufacturing sector that were not part of this study.

\section{References}

Abaho, E. (2014) Antecedents of entrepreneurial values among university students in Uganda. Un Published PhD. Thesis. University of Dar es salaam - Tanzania.

Abdelmohsen, M., Desoky, G. \& Mousa, A. (2013). An empirical investigation of the influence of ownership concentration and identity on firm performance of Egyptian listed companies. Journal of Accounting in Emerging Economies, 3(2), 164 - 188.

Ahimbisibwe, G. M., Nkundabanyanga, S. K., Nkurunziza, G. \& Nyamuyonjo, D. (2016). Knowledge absorptive capacity: do all its dimensions matter for export performance of SMEs? World Journal of Entrepreneurship, Management and Sustainable Development, 12(2), 139-160

Al-Saidi, M. \& Al-shammari, B. (2013). Board Composition and Bank performance in Kuwait: An Empirical Study. Managerial Auditing Journal, 28(6), 472-494.

Baisi, M. D. (2008). The dynamics of SME Financing Decisions and performance in a developing Economy. The Case of Tanzania. Un published PhD. Thesis. University of Dar es salaam, Tanzania.

Berle, A. A. Jr. \& Means, G. C. (1932). The Modern Corporation and Private Property. New York: MacMillan

Bathula, H. (2008). Board Characteristic and firm performance. Published PhD Thesis Auckland University of Technology. New Zealand

Brown, R. (2008). Business Ethics. Canadian Business Review, 21(1), 39.

Catalyst. (2011). Improving financial performance: Why Diversity Matters. Catalyst Information Centre

Clarke, T. (2004). Cycles of Crisis and Regulation: The enduring Agency and stewardship problems of corporate governance. An international review, 12(2), 153-161.

Cronbach, L. J. (1951). Coefficient Alpha and the Internal Structure of the Tests. Psychometrika, 16, 297-334.

Dagsson, S. (2011). Published Master's Thesis. How Age Diversity on the Board of Directors' Effects on Firm Performance.

Donaldson, T. \& Preston, L. E. (1995). The Stakeholder Theory of the Corporation: Concepts, Evidence, and Implications. The Academy of Management Review, 20(1), 65-91

Davies, M. \& Schlitzer, B. (2008). The impracticality of an international, one size fits all corporate governance code of best practice. Managerial Auditing Journal, 23(6), 532-544.

Field, A. (2006). Discovering Statistics using SPSS (2nd Ed.). Sage, London.

Freeman, R. E., Wicks. A. C. \& Parmar, B. (2004). Stakeholder theory and The corporate objective Revisited. Organisational Science, 15(3), 364-369.

Freeman, R. E. (1984) Strategic Management: A Stakeholder approach, Marshfield, MA: Pitman.

Fu, H. \& Yu, X. (2008). Is Board structure one-size-fits-all? The Unintended Informational Consequence of the Sarbanes-Oxley Act.

Government of Uganda. (2000). Report of the Judicial Commission of Inquiry into Closure of Banks, November. 
Hofmann, E. \& Lampe, K. (2013). Financial statement analysis of logistics service providers: ways of enhancing performance. International Journal of Physical Distribution \& Logistics Management, 43 (4), 321-342.

Huse, M. (2005). Outside Directors in SME Boards: A call for theoretical reflections On Corporate Board. Role, Duties \& Composition, 1(1).

Ishengoma, E. K. \& Kappel, R. (2008). Business Constraints and Growth Potential of Micro and Small Manufacturing Enterprises in Uganda. Working Paper; Transformation in the Process of Globalisation.

Jensen, M. C. \& Meckling, W. H. (1976). Theory of the Firm: Managerial Behavior, Agency costs And Ownership Structure. Journal of Financial Economics, 3(1), 305-360.

Ji-Li, C., Lung Chu, W., Kevin, C. K. L. \& Liao, S. (2011). Age diversity and firm performance in an emerging economy. Implications for cross-cultural human resource management, 50(10), 1002

Kamukama, N. (2011). Intellectual Capital and Firm Performance Un Published PhD. Thesis. Makerere University- Uganda.

Kasekende, L. \& Opondo, H. (2003) Financing small and medium-scale enterprises (SMEs): Uganda's experience. BOU working paper.

Khan, A. \& Awan, S. H. (2012). Effect of Board composition on firm's performance of Pakistani listed Companies. Journal of Contemporary Research in Business, 3(10), 853

Krejcie, P. \& Morgan, D. W. (1970). Determining sample size for research activities. Educational and Psychological Measurement, 30(3), 7-10.

Kreusel, N. \& Christian, N. (2008). Performance Measurement in SMEs: Literature Review and results from a German case study. International Journal of Globalisation and small scale Business, 2(4), 411-427.

Kunze, F., Boehm, S. \& Bruch, H., (2013). Organizational Performance Consequences of Age Diversity: Inspecting the Role of Diversity-Friendly HR Policies and Top Managers' Negative Age Stereotypes. Journal of Management Studies, 50(3), 10-11

Li, J., Chris, W. L., Chu, L. K. \& Liao, S. (2011). (Un published) Age Diversity and Firm Performance In an Emerging Economy, Implications for Cross-Cultural Human Resource Management

Likert, R. (1932). A technique for the measurement of attitudes. Archives of Psychology, 140(7), 15-20 (Series A).

Liu, H. \& Michelle, W. L. F. (2010). Board characteristics of medium and large Chinese companies.

Masoud, M. S. (2005). Effect of stake holder attributes and managers 'value on stake holder salience. Published PhD Thesis. University of Dar es salaam. Tanzania.

Martin, M. (2013). Assessing the model risk with respect to the interest rate term structure under Solvency II. The Journal of Risk Finance, 14(3), 200-233.

Melyoki, L. L. (2005). Determinants of Effective Corporate Governance in Tanzania Published PhD Dissertation. University of Twenty, The Netherlands.

MoFPED. (2012). Background to the Budget 2012/2013 Fiscal Year. Kampala: Government of Uganda.

Muneer, S., Bajuri, N. H. \& Rehman, S. U. (2013). Moderating Affect of Agency Cost on the Relationship between Capital Structure, Dividend Policy and Organization Performance: a Brief Literature Review. Actual Problems of Economics, 11(149), 434- 442.

Mutambi, J. (2011). Stimulating Industrial Development in Uganda through Open Innovation. Business Incubators. Blekinge Institute of Technology Licentiate Dissertation Series, 10(2), 1650-2140.

Mutambi, J., Byaruhanga, J. K., Buhwezi, B. K. \& Trojer, L. (2010). Research on the State of Business Incubation Systems in Different Countries: Lessons for Uganda. African Journal of Science, Technology, Innovation and Development, 2(2), 190 - 214.

Nkundabanyanga, S. (2012) Board governance, Intellectual Capital and Firm Performance. Un Published PhD. Thesis. Makerere University- Uganda.

Nkundabanyanga, S. K., (2016), Board governance, intellectual capital and firm performance: importance of multiplicative effects. Journal of Economic and Administrative Sciences, 32(1), 20 - 45

NPA. (2010). Uganda Vision 2040, Republic of Uganda, National Planning Authority.

Nyirenda, M. (2010). Board composition in companies listed on the Johannesburg Securities Exchange. Published Masters Dissertation. University of Pretoria, South Africa

Ocici, C. (2006). A Working Paper on Entrepreneurship Presented at National Consultation Conference: Legal empowerment of the poor. 
Orobia, A. L., Byabashaija, W., Munene, C. J., Sejjaaka, K. S. \& Musinguzi, D. (2013). How do small business owners manage working capital in an emerging economy? A qualitative inquiry, Qualitative Research in Accounting \& Management, 10(2), 127-143.

Pandey, I. M. (1997). Financial Management, $7^{\text {th }}$ Ed. Vikas publishing house Pvt. Ltd.

Pastoriza, D. \& Miguel, A. (2008). When agents become stewards: Introducing learning in the Stewardship theory.

Pfeffer, J. \& Salancik, G. R. (1978). The External Control of Organizations: A Resource Dependence perspective. New York; Harper and Row.

Pfeffer, J. (1972). Size and composition of corporate boards of directors: The Organization and its Environment. Administrative Science Quarterly, 17(2), 218-228

Siciliano, J. (1996). The relationship of board member Diversity to Organisational Performance. Journal of Business Ethics, 15, 1313-1320

The Uganda Manufacturers Association Business Directory, UMA (2014)

The World Bank Annual Report. (2013). End extreme poverty. Promote shared prosperity. The Financial Data and Organizational Information, and the World Bank Corporate Scorecard Available at: http://go.worldbank.org.

Tumwine, S., Akisimire, R., Kamukama, N. \& Mutaremwa, G. (2015). A borrowing cost model for effective performance of SMEs in Uganda. World Journal of Entrepreneurship, Management and Sustainable Development, 11(2), 74-89

UBOS. (2011). Census of Business Establishments. Government of Uganda.

UBOS. (2015). Census of Business Establishments. Government of Uganda.

UNIDO. (2013). The Role of Manufacturing and Structural Change; Industrial Development Report 2013, Kampala.

Wellalage, N. H. \& Locke, S. (2013). Corporate Governance. Board Diversity and Firm Financial, 8 (2), 116-136. 